\title{
Solar Cooling Technologies in Jordan: A Technical Study
}

\author{
YOUNIS BADRAN \\ Hebron Industrial Secondary School \\ Palestinian Ministry of Education and Higher Education \\ STATE OF PALESTINE
}

ISHAQ SIDER

Mechanical Engineering Department

Palestine Polytechnic University

STATE OF PALESTINE

\begin{abstract}
In the recent years, solar cooling technologies for buildings have garnered increased attention. This study aimed to evaluate the performance of current solar thermal and solar photovoltaic (PV) air-conditioning technologies. Hence, the annual heating/cooling load profile and energy consumption of a reference building in the climate of Aqaba, Jordan were simulated using the TRNSYS software. The solar thermal and solar PV air-conditioning systems were designed and simulated to compensate the cooling demands. It was found that the annual cooling energy accounted for $96.3 \%$ of the total annual energy demand (heating plus cooling) of the reference building. The solar PV and solar thermal air-conditioning systems compensated for direct cooling by $35.8 \%$ and $30.9 \%$, respectively, and the corresponding compensations of cooling energy by the storage system were $7.3 \%$ and $11.9 \%$, respectively. Thus, through this comparative study, we found that the storage system significantly contributed in compensating the cooling demands of the solar thermal system; however, the compensation to direct cooling was lower relative to the solar PV system.
\end{abstract}

Key-Words: Storage; Direct cooling energy; Solar photovoltaic cooling; Solar thermal cooling; TRNSYS.

Received: April 29, 2021. Revised: September 19, 2021. Accepted: September 30, 2021. Published: October 8, 2021

\section{Introduction}

Traditional air-conditioning systems primarily use refrigeration systems that significantly contribute to global warming. Solar air-conditioning systems, on the other hand, do not use environmentally harmful refrigerants. [1]. Using solar energy for heating and cooling seems to be an appealing approach that can help boost the renewable and sustainable energy shares in the overall energy consumption. Furthermore, it can minimize the use of oil and coal and consequently, avoid the hazardous environmental consequences of such conventional sources. One of the aspects or characteristics while researching solar cooling systems is the connection between the resource availability and demand [2], [3]. Air-conditioning based solar energy can be accomplished using either solar thermal or solar photovoltaic (PV) systems. There are two types of solar cooling systems: (I) photovoltaic systems associated with vapor compression cooling machines, and (ii) solar thermal systems linked with thermally powered chillers; and both these systems are commercially available [4]. According to a technical report on subtask B16, over 100 large scale solar thermal cooling systems and about 150 smallscale systems were deployed around the world, including systems that are presently not in use. There are about 250 installations in Europe, and 13 in Asia, primarily in China and Japan [5], [6].

Two air-source heat pumps with rated cooling and heating capabilities of $23.8 \mathrm{~kW}$ and $33 \mathrm{~kW}$, respectively, were employed as an auxiliary system for the installation of the solar cooling and heating systems. In 2018, the average coefficient of performance for cooling (COP) COPhp,c was 2.83, with values of 2.74 and 2.75 in July and August, respectively, and the average coefficient of performance for heating COPhp,h was 3.20 [7]. In the sub-Mediterranean settings, solar thermal absorption cooling systems show some potential. Jordan currently has 4 locations with water-lithium bromide $\left(\mathrm{H}_{2} \mathrm{O}-\mathrm{LiBr}\right)$ absorption chillers with a total nominal capacity of $530 \mathrm{~kW}$. The reported research project is based on a prototype system aided with a cooling capacity of $160 \mathrm{~kW}$ on the German Jordanian University (GJU) campus [8].

The development of solar cooling systems for buildings in the 1990s was largely focused on 
thermal processes, such as open systems and closed absorption or adsorption processes. Furthermore, PV module prices have decreased considerably during the last decade. The most common solar-powered cooling method is based on operating high COP vapour compression chillers $(\mathrm{COPe} \approx 4-6)$ that are linked to the solar PV modules. Because of its minimal maintenance and appropriateness for smallscale applications, this technology is very straightforward [9]. Vapour compression systems powered by PV solar collectors are the most costeffective solar air-conditioning systems. However, bringing PV systems to the market is much more difficult than installing solar thermal power plants; cost reductions for PV systems are projected to be faster [6], [10], [11]. Recently, the economic performance of PV systems for DHW has made them increasingly appealing, not only because of decreasing PV module costs, but also because of the critical role DHW and thermal energy storage play in boosting PV integration and self-consumption in buildings. In terms of using solar PV airconditioning for cooling applications, numerous authors conducted significant research to evaluate various solar cooling setups, taking into account both thermally driven and solar electric systems [12][14].

During the primary cooling season, conventional airconditioning is one of the largest consumers of electrical energy in many Middle Eastern (ME) nations. This causes a large rise in peak electric power consumption throughout the summer, often exceeding the capacity limitations of the network and posing the risk of blackouts (5). The simulated analysis of a PV cooling system for a 2-storey residential structure revealed that it can generate its own necessary power under the MENA region's climate parameters [15]. In this scenario, the PV cooling system operates autonomously, independent of the power grid, by utilizing an electric battery and a cold-water storage tank [15]-[17].

According to Jordan's Department of Statistics (DOS), a kind of single-family home (SFH), known as a 'Dar', accounts for around 72 percent of total residential structures in the nation [16]. During the summer, this industry is one of Jordan's largest consumers of electrical energy. Jordan, in particular, receives significantly intense solar radiations, making solar cooling systems (both thermal and PV) an appealing choice for residential structures. However, there have been few limited researches on solar cooling methods in Jordan. As a result, based on technical considerations, the most appropriate of the two technologies for the Jordanian climate must be determined. The purpose of this research is to provide a systematic technique for analysing and comparing the performance of solar thermal and solar PV air-conditioning technologies in Aqaba's environment.

\section{Methodology}

Jordan, with an area of $89,329 \mathrm{~km}^{2}$, is located $80 \mathrm{~km}$ to the east of the Mediterranean Sea, between the $29110^{\circ} \mathrm{N}$ and $32420^{\circ} \mathrm{N}$ latitudes and $34.540^{\circ} \mathrm{E}$ and $38.150^{\circ}$ E longitudes [18]. The bulk of Jordan's SFHs share the same architectural design: a flat roof, a guest room, a living area, a kitchen, and 2 or 3 bedrooms and bathrooms. Under the local weather conditions, the SFH Aqaba was used as the reference building for this study [19]. The TRNSYS software was used to model and analyse the cooling and heating load profiles of the SFH. The simulations made use of Aqaba's hourly weather data.

Two types of cooling technologies were modelled to compensate for the cooling load demands of the SFH. The hourly cooling load profiles for each type were generated using the TRNSYS and MatlabSimulink software. Comparative studies and analyses were conducted on the simulation results of the 2 types of aforementioned technologies.

\subsection{Simulation Model of the Building}

\subsubsection{Reference Building}

Fig. 1 depicts the architectural design of the SFH, which has a floor area of $224 \mathrm{~m}^{2}$ and an internal ceiling height of $2.86 \mathrm{~m}$. The guest and living rooms each featured a window that faced south. The outside walls were constructed using stone, concrete, concrete blocks, and plaster. In the reference building, single-glazed windows with $\mathrm{U}$-values of $5.68 \mathrm{~W} / \mathrm{m}^{2}$ were utilized, which is one of Jordan's most frequently adopted window types. On the east and west façades, the optimal window area was $20 \%$ of the wall's total surface area. The window area on the north façade was $10 \%$, whereas the window area on the south face was $30 \%$.

The internal gain was chosen based on the ISO 7730 standard, with a maximum of 6 passengers in the $\mathrm{SFH}$. The value of the infiltration rate and the cooling and heating set points were defined according to the ASHRAE standards. For cooling, a dry bulb temperature of $24{ }^{\circ} \mathrm{C}$ and a maximum relative humidity of 50-65\% were considered. For heating, a dry bulb temperature of $20^{\circ} \mathrm{C}$ and a $30 \%$ relative humidity were considered. The building and 
occupant ventilation components were considered based on the ASHRAE standards [20]-[22].

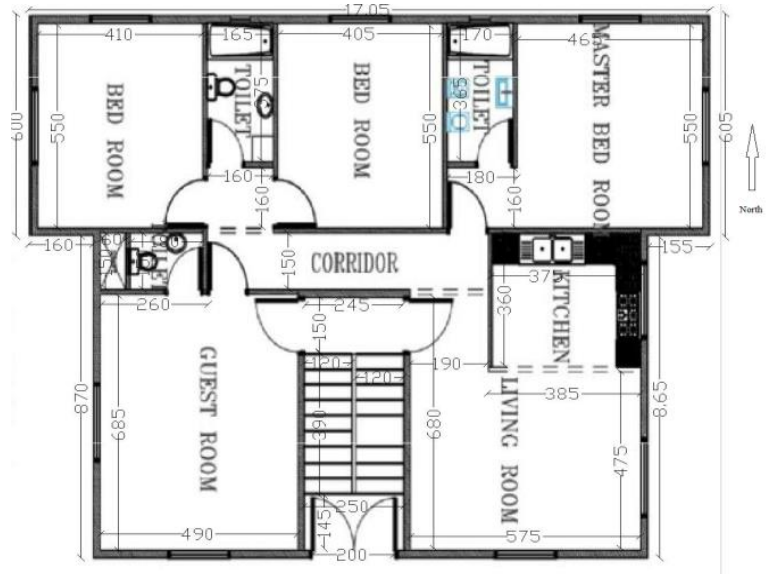

Fig. 1: Schematic of a single-family house (SFH) in Aqaba.

Note: The unit for the dimensions is $\mathrm{cm}$

\subsubsection{Location and Climatic Condition}

The meteorological file for Aqaba was saved in the EnergyPlus Weather (EPW) format. This hourly dataset consists of the horizontal solar radiation (beam, diffuse, and global), ambient air temperature, and relative humidity. These meteorological data were used to formulate study's final results [23].

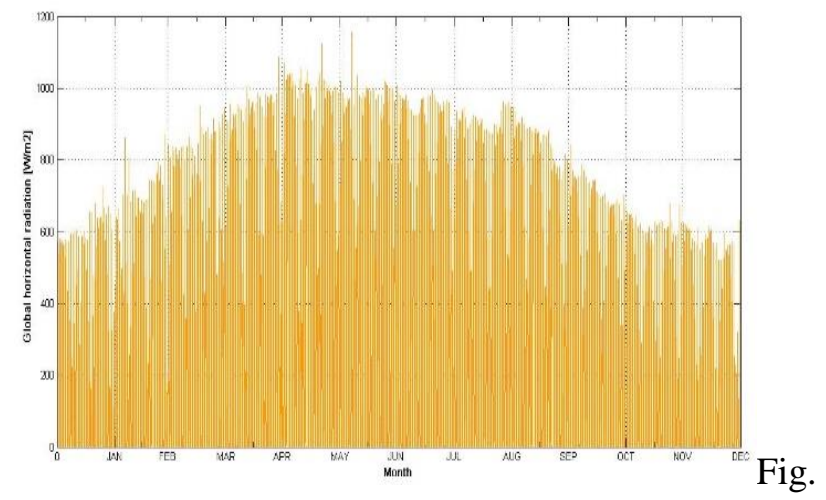

2: Yearly global horizontal solar radiation of Aqaba.

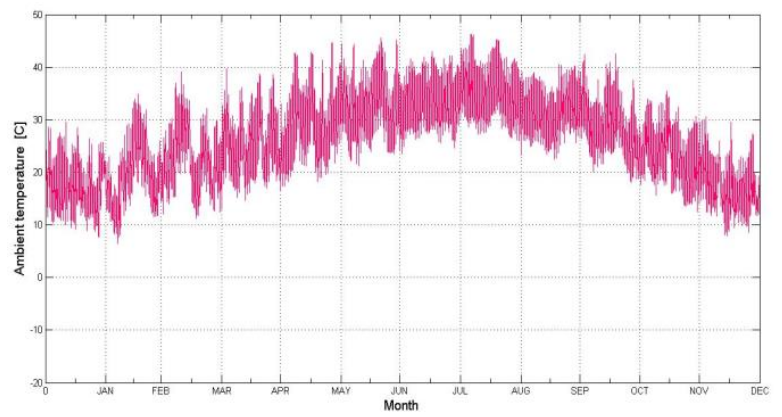

Fig. 3: Yearly ambient air temperatures of Aqaba

Fig. 2 depicts the worldwide horizontal solar radiation pattern of Aqaba, where the daily peak global horizontal solar radiation reaches $1000 \mathrm{~W} / \mathrm{m}^{2}$ in summer and $600 \mathrm{~W} / \mathrm{m}^{2}$ in winter. Fig. 3 shows the yearly ambient temperature of Aqaba, where it reaches $45^{\circ} \mathrm{C}$ in summer and $30^{\circ} \mathrm{C}$ in winter.

\subsubsection{Building Heating and Cooling Loads}

The TRANSYS software, a transient system simulation program, was used to model the ' cooling and heating requirements of the SFH. The program contains a vast repository of constructed elements, which are often tested by experiments. The TRNSYS includes two appropriate programs, namely, the TRNSYS Simulation Studio and Multi-zone Building (TRNBuild). TRNSYS TYPE56 was used to simulate heat conduction, convection, and infiltration through the SFH envelope's surfaces.

The external climatic conditions, internal design circumstances, and SFH envelope structure all had an impact on the computational results. TRNSYS based all computations on a heat balance approach and utilized a transfer function technique (TFM) to obtain the conductive heat gain at the surface of each wall as a simplification of the laborious heat balancing approach [24].

$q_{s, i}=\sum_{k=0}^{n b_{i}} b_{s}^{k} T_{s, o}^{k}-\sum_{k=0}^{n_{c s}} C_{s}^{k} T_{s, i}^{k}-$ $\sum_{k=1}^{n d_{s}} d_{s}^{k} q_{s, i}^{k}$,

$q_{s, o}=\sum_{k=0}^{n a_{s}} a_{s}^{k} T_{s, o}^{k}-\sum_{k=0}^{n_{b s}} b_{s}^{k} T_{s, i}^{k}-$ $\sum_{k=1}^{n d_{s}} d_{s}^{k} q_{s, o}^{k}$,

where $\mathrm{q}_{\mathrm{s}}$ represents the heat flux $(\mathrm{kJ} / \mathrm{h})$ transmitted through the wall. $a_{s}, b_{s}, c_{s}$, and $d_{s}$ are the $Z$ transforms of the surface temperature and heat flow calculated using the literature's z-transfer function algorithms. $\boldsymbol{k}$ is a time series term that is supplied by the user inside the TRN build description. The heat gain by convection is computed using the equation below:

$q_{s, i}=q_{c o m b, s, i}+S_{s, i}+$ Wallgain,

$q_{s, o}=q_{c o m b, s, i}+S_{s, i}$.

where, $\mathrm{q}_{\mathrm{comb}, \mathrm{s}, \mathrm{i} / \mathrm{i}}$ is associated with the combined convective and long wave radiation of the inner/outer surface. 


$$
\begin{aligned}
& q_{c o m b, s, i}=\frac{1}{R_{\text {equiv }, i} \times A_{s, i}}\left(T_{s, i}-T_{\text {star }}\right), \\
& q_{c o m b, s, o}=q_{c, s, o}+q_{r, s, o}, \\
& q_{c, s, o}=h_{\text {conv }, s, o}\left(T_{a, s}-T_{s, o}\right), \\
& q_{r, s, o}=\sigma \varepsilon_{s, o}\left(T^{4}{ }_{s, o}-T^{4}{ }_{f s k y}\right),
\end{aligned}
$$

The maximum cooling power demand of the SFH was considered to be $15 \mathrm{~kW}$, as shown in Fig. 4. This means that the solar air conditioning systems presented in this study must compensate for a cooling peak of $15 \mathrm{~kW}$. Given that the specified compression chiller has a COP of 3, the AC peak output must be up to $5 \mathrm{~kW}$. The system components were sized and designed.

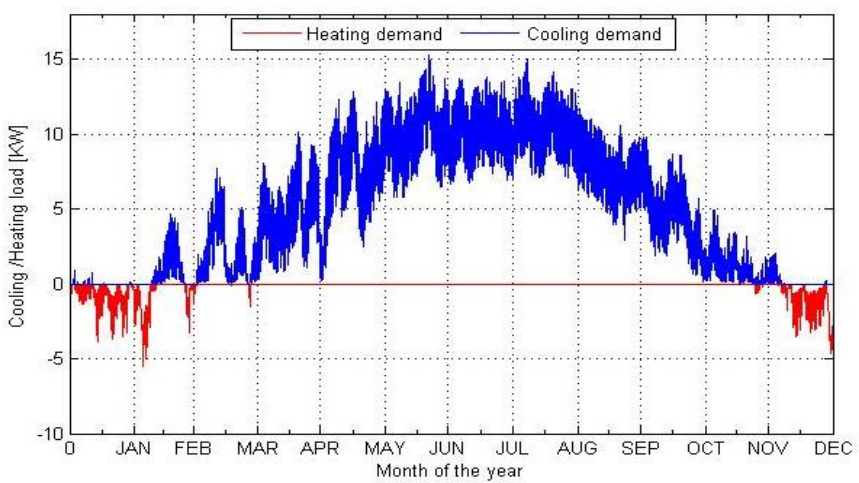

Fig. 4: Annual heating and cooling loads.

According to Fig. 4, the highest cooling load can be observed between June and August in the 14.8$15.3 \mathrm{~kW}$ range, while the lowest between January and December. Furthermore, this figure shows that a significantly high cooling load (approximately 8$10 \mathrm{~kW}$ ) is consumed during the night as well as the daytime. The cooling load performance along the year is dependent on the external ambient temperature and solar radiation as shown in Fig. 2 and Fig. 3. This dependence is due to the solar thermal gain through the building envelope.

Fig. 5 shows the total annual thermal energy demand for the SFH, where the annual cooling load is 43,490 $\mathrm{kWh} /$ year and the total heating load is 1635 $\mathrm{kWh} /$ year. However, $96.3 \%$ of the annual thermal energy demand comprises of the cooling load.

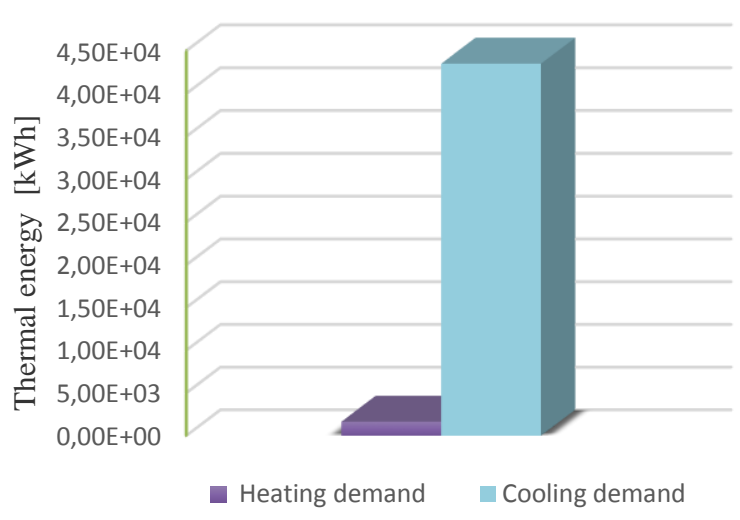

Fig. 5: Annual heating and cooling energy demands.

The results in Fig. 6 show the cooling energy demand over a period of 10 months i.e., from February to the end of November. However, the heating energy period was quite short (January, February, and December). The results show the importance of cooling compared to heating in Aqaba.

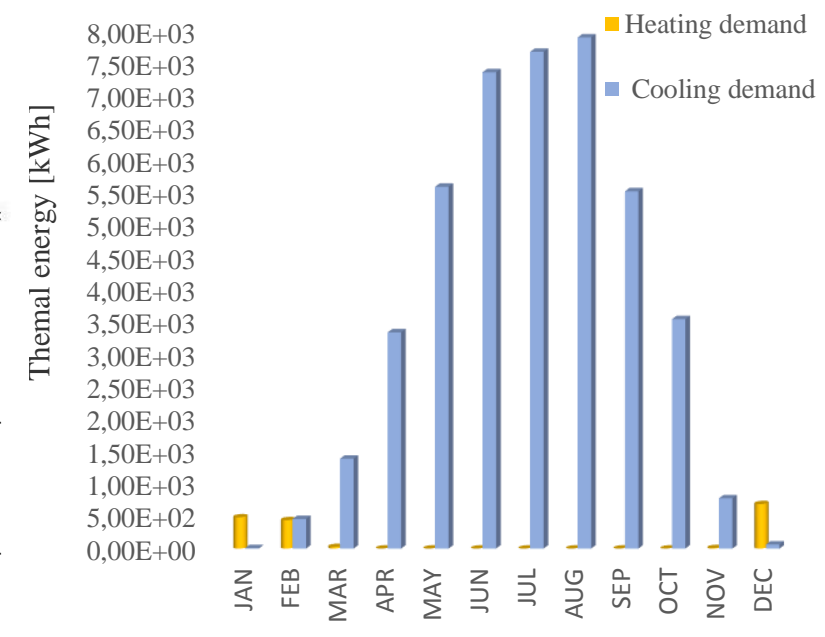

Fig. 6: Monthly heating and cooling energy demands.

\subsection{Solar Cooling Air-Conditioning Systems}

To attain the objective of this study, 2 airconditioning systems were designed and simulated to compensate the cooling load demand for the SFH as follows. This was based on the cooling load demand results of the SFH. The design, muddling, and simulation for each system were conducted to compensate the total energy demand. The simulation of cooling production by each system was performed using Matlab-Simulink, where the solar radiation on the tilted surfaces was calculated using the TRNSYS software. 


\subsubsection{Case 1: Solar PV Air-Conditioning System} Fig. 7 depicts the major components of a PV airconditioning system. A PV module converts solar energy into a DC power. The solar charge controller regulates the voltage and current generated by the PV module and supplied to the battery. The inverter converts $\mathrm{DC}$ to $\mathrm{AC}$ to power the compression chiller (AC). If no cooling is required, the battery bank stores the excess energy.

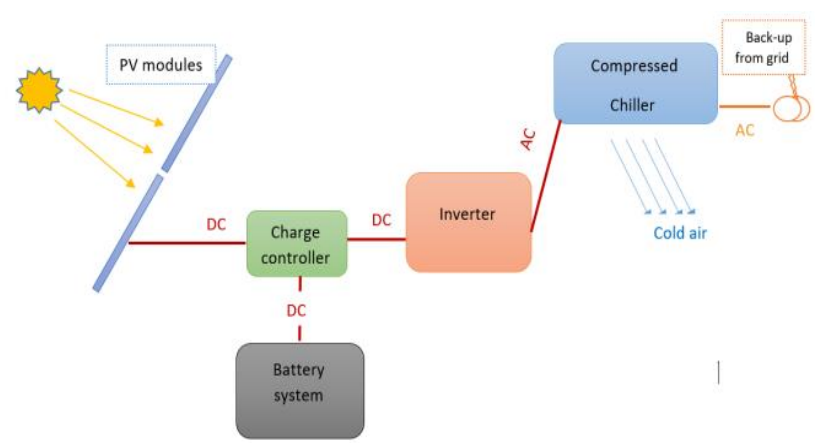

Fig. 7: Solar PV air-conditioning.

The compression chiller converts the AC power to cold air when the solar radiation is insufficient to meet the cooling demand. This compression chiller receives backup electric power from the grid when DC power from the PV array and battery bank is inadequate, especially at night.

$$
\begin{aligned}
& C O P= \\
& \frac{Q}{W^{\cdot} t(e 1)} \\
& 5 k W
\end{aligned}\left(\frac{\text { useful thermal cooling capacity }}{\text { input electrical power }}\right)=\frac{15}{3}=
$$

Thus, $20 \%$ of power is added to this number to compensate for power losses in the inverter and battery system. As a result, the necessary peak DC power is equal to

Electric peak power required $=5 \mathrm{~kW} \times$

$$
\begin{aligned}
& 1.2= \\
& 6 \mathrm{~kW},
\end{aligned}
$$

\section{Number of PV modules required $=$} $\frac{\text { Peak power required }}{\text { Peak power of } P V \text { module }}$

$$
\begin{aligned}
& \text { Number of } P V \text { modules required }= \\
& \frac{6 \mathrm{kWp}}{0.225 \mathrm{kWp}}=26.66= \\
& 27 \text { modules. }
\end{aligned}
$$

The PV array on the system was designed to face south. The tilt angle corresponds to Aqaba's latitude of $29^{\circ} 31^{\prime}$ N. A 6-kW capacity (44-64) V DC, $230 \mathrm{~V}$ $\mathrm{AC} / 50 \mathrm{~Hz}$ inverter with a peak efficiency of $95.4 \%$ was utilized for this system. The battery bank was built to hold enough energy for 2 days. The excess energy was calculated using the simulated data from a PV air-conditioning system that did not have any storage. Ten days in April were selected with an increased cooling capacity, and the average daily excess cooling energy was calculated to be 18.32 $\mathrm{kWh} /$ day. The average daily DC excess energy $\mathrm{E}_{\mathrm{c}, \text { daily }}$ that should be stored was calculated to be 6.4 $\mathrm{kWh} /$ day.

$$
E_{C, \text { daily }}=\frac{\text { average daily of Excess cooling Energy }}{C O P} \times
$$$$
\eta_{\text {inv }}
$$

$C_{\text {Nom,Batt }}=\frac{E_{C, \text { daily }} \text { X AF }}{\eta_{B a t, i n v} \text { X DOD X VBatt }}$,

$C_{\text {Nom,Batt }}=\frac{6.4 \times 2}{085 \times 0.8 \times 48}=392 \mathrm{Ah}$

From the above calculations, we conclude that this system required a 392 Ah battery. As a result, $812 \mathrm{~V}$ batteries were required, with 4 batteries linked in series. For the purpose of PV air-conditioning, a controller with a current of $105.7 \mathrm{~A}$ and voltage of $48 \mathrm{~V}$ (DC) was used.

The simulation was run for 1 year with a 15 min time step in Matlab-Simulink using the 2-time series as input. Equations 14, 15, and 16 were used to determine the DC power generated by the PV array. Here, the $\eta_{p v}$ represents the PV module efficiency and $A_{p v}$ refers to the PV array area. The module efficiency under standard test conditions (STC) is $\eta_{S T C}$ and the temperature coefficient of the module is $\alpha_{p v}$

$$
\begin{aligned}
& \mathrm{P}_{\text {PV-electric }}=\eta_{P V} \times G_{\text {tilt }} \times A_{p v} \\
& \eta_{P V}=\eta_{S T C} \times\left(1-\alpha_{p v}\right) \times\left(T_{C}-T_{S T C}\right) \\
& T C=T_{a m b}+\left(T_{N O C T}-20^{O} C\right) \times \frac{G_{t i l t}}{800}
\end{aligned}
$$

The inverter converts DC into AC, which is represented as $\mathrm{P}_{\text {Inv-electric, and the inverter }}$ efficiency was calculated to be $\eta_{I n v=95.4 \%}$. $\mathrm{P}_{\text {Inv-electric }}=\mathrm{P}_{\mathrm{PV} \text {-electric }} \times \eta_{\text {Inv }}$ 
The compressed chiller converts the $\mathrm{AC}$ power into cooling power $\mathrm{P}_{\mathrm{c}-\text { coolling }}$ as follows:

$\mathrm{P}_{\mathrm{c}-\text { coolling }}=\mathrm{COP} \times \mathrm{P}_{\text {Inv-electric }}$

The excess and standby cooling powers were determined by deducting the PV air-conditioning system's output cooling power from the SFH cooling power requirement (19). If the resultant value was positive, then the excess cooling power $\mathrm{P}_{\text {Excess1 }}$ was available. If it was negative, back-up cooling power $\mathrm{P}_{\text {Back-up-cooling1 }}$ was necessary. The latter was compensated by the back-up system connected to the grid.

$\mathrm{P}_{\text {Excess1 }}$ Back-up-cooling1 $=\mathrm{P}_{\mathrm{c}-\text { coolling }}-$
$\mathrm{P}_{\text {demand }}$ (19)

The electric power charged in the battery system $\mathrm{P}_{\text {Batt-chrge, was calculated using Equation 20, with }}$ an estimated battery efficiency of $85 \%$ and a maximum battery capacity of $6.4 \mathrm{kWh}$.

$\mathrm{P}_{\text {Batt-chrge }}=\mathrm{P}_{\text {Excess-DC }} \times \eta_{B a t, I n v}<$ Maximum battery capacity

Subsequently, the cooling power generated by the contribution of the discharging of the battery system

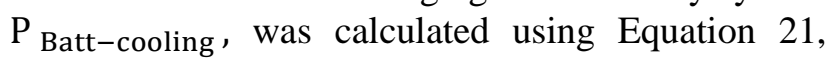
where the DOD was considered to be $80 \%$.

$\mathrm{P}_{\text {Batt-cooling }}=\mathrm{P}_{\text {Batt-chrge }} \times D O D \times C O P$

The back-up cooling energy that should be provided using the grid $\mathrm{E}_{\text {Back-up-cooling2 }}$ can be calculated using Equation 22.

$\mathrm{E}_{\text {Back-up -cooling2 }}=$

$\int_{0}^{\mathrm{t}} \mathrm{P}_{\text {Back-up-cooling1 }} \mathrm{dt}-$

$\int_{0}^{\mathrm{t}} \mathrm{P}_{\text {Batt-cooling }} \mathrm{dt}$

\subsubsection{Case 2: Solar Thermal Air-Conditioning System}

Most solar thermal cooling systems installed today are based on absorption chillers. Fig. 8 shows an absorption chiller coupled with a solar heating system and an auxiliary energy supply as a back-up electric heater. The collector converts the solar radiation into heat, and the pump subsequently, delivers it to the storage tank. The storage tank then supplies the absorption chiller with the thermal energy to produce cold water.

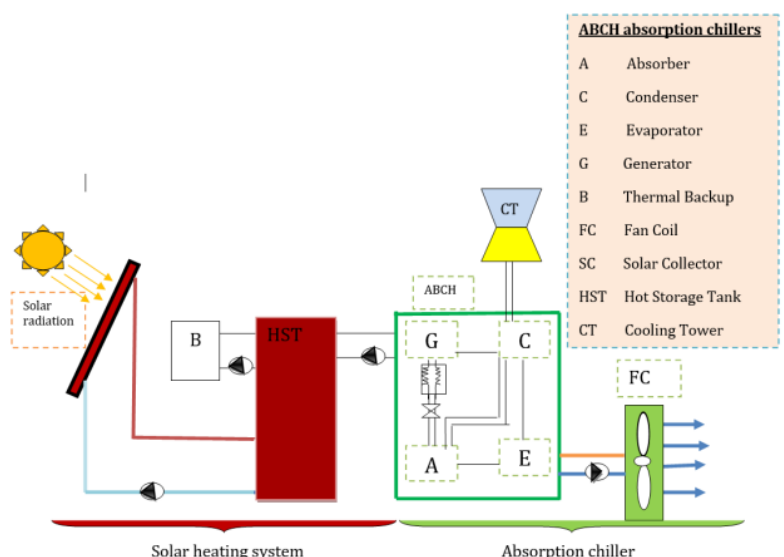

Fig. 8: Solar thermal Air-Conditioning System

The cooling power is transferred from the cold water to the SFH's interior air via the coil and fan system and is dispersed throughout the structure using a duct system. A typical backup electric heater attached directly to the storage tank can provide heat if the solar heat is insufficient, for example, at night or on gloomy days [16], [17].

A single design point may be used to make a very basic evaluation (rule of thumb) of the collector size in a solar-assisted air-conditioning system, according to Qawasmeh et al. [16]. Equation 9 may be used to select the particular collector area, which is defined as the collector area per nominal cooling capacity.

$A_{\frac{\text { coll }}{m^{2}}}=\frac{1}{G \cdot \eta_{\text {coll }} \cdot \mathrm{COP}}$,

where $\mathrm{G}$ denotes the global radiation $\left(\mathrm{W} / \mathrm{m}^{2}\right)$ and $\eta_{\text {coll }}$ denotes the collector efficiency at the design condition.

For this study, $\mathrm{G}=800 \mathrm{~W} / \mathrm{m}^{2}, \eta_{\text {coll }}=50 \%, \mathrm{COP}=$ 0.7 , and the resultant specific collector area was $\mathrm{A}_{\text {coll,Spec }}=3.5 \mathrm{~m}^{2}$ for a $1 \mathrm{~kW}$ cooling capacity. As shown in Fig. 2, the solar radiation for Aqaba in summer reaches $1000 \mathrm{~W} / \mathrm{m}^{2}$. This implies a specific collector area of $\mathrm{A}_{\text {coll,Spec }}=3.5 \mathrm{~m}^{2}$ for a $1 \mathrm{~kW}$ cooling capacity, which is required for this case. However, as shown in Fig. 6, the maximum cooling load demand of the SFH in Aqaba was $15 \mathrm{~kW}$. Therefore, the collector area of the system was set at $52 \mathrm{~m}^{2}$. This case was provided with a high-quality flat plate collector by the Schüco Company. A $\mathrm{H}_{2} \mathrm{O}-\mathrm{LiBr}$ absorption chiller with a COP of 0.7 and a notional cooling capacity of $15 \mathrm{~kW}$ was used in Madrid. Madrid has a Mediterranean climate similar to Aqaba, with $1000 \mathrm{~W} / \mathrm{m}^{2}$ of solar radiation in the 
summer. With a nominal capacity of $15 \mathrm{~kW}$ and a coefficient of performance (COP) of 0.71 , a singleeffect $\mathrm{H}_{2} \mathrm{O}-\mathrm{LiBr}$ absorption chiller was used.

The system was intended to operate within the manufacturer's device specifications, as shown in Table 1. A fan coil served as the cooling distribution system [16], [17].

Table 1. $\mathrm{H}_{2} \mathrm{O}-\mathrm{LiBr}$ absorption chiller parameters compiled from [25].

\begin{tabular}{|l|c|}
\hline \multicolumn{1}{|c|}{ Parameter } & \multicolumn{1}{c|}{$\begin{array}{c}\text { Absorption chiller } \\
\left(\mathbf{H}_{2} \mathbf{O}-\mathbf{L i B r}\right)\end{array}$} \\
\hline Manufacturer & EAW \\
\hline Designation & Wegracal SE 15ACS15 \\
\hline Technology & Absorption \\
\hline Sorbent refrigerant & $\mathrm{LiBr} / \mathrm{H}_{2} \mathrm{O}$ \\
\hline Cooling capacity $(\mathrm{Kw})$ & 15 \\
\hline COP $(-)$ & 0.71 \\
\hline Heating temperature $\left({ }^{\circ} \mathrm{C}\right)$ & $90 / 80$ \\
\hline Re-cooling temperature $\left({ }^{\circ} \mathrm{C}\right)$ & $30 / 35$ \\
\hline Cold water temperature $\left({ }^{\circ} \mathrm{C}\right)$ & $17 / 11$ \\
\hline Electricity demand $(\mathrm{W})$ & 30 \\
\hline Hot water $\left(\mathrm{m}^{3} / \mathrm{h}\right)$ & 2 \\
\hline Cold water $\left(\mathrm{m}^{3} / \mathrm{h}\right)$ & 5 \\
\hline
\end{tabular}

This section provides a step-by-step description of the simulation and methodical model, which was developed using Matlab-Simulink, for the SFH's location and climatic conditions, as well as its cooling load requirement. Schüco Company's chosen absorption chiller and flat plate collector were utilized to ease the procedure.

Equation 24 is used to determine the heat power required by the absorption chiller $\mathrm{P}_{\mathrm{hABCH}}{ }^{\text {h. }}$ :

$P_{h B A H}{ }^{h}=\frac{\text { P cool load }}{\operatorname{COP}_{A B C H}}$

where, $\mathrm{P}_{\text {cool- load }}{ }^{\mathrm{c}}$ and $\mathrm{COP}_{\mathrm{ABCH}}$ denote the cooling power demands and: coefficient of performance of the absorption chiller.

The following equations were used to determine the collector's heat power production $\mathrm{P}_{\text {coll. }}^{\mathrm{h}}(25-26)$ [5]:

$$
\begin{aligned}
& P_{\text {coll }}^{h}=\eta_{\text {coll }} \times G_{\text {tilt }} \times A_{\text {coll }}, \\
& \eta_{\text {coll }}=\eta_{o} \times C_{1} \frac{\left(T_{\text {coll }}-T_{a m b}\right)}{G_{\text {tilt }}}-C_{2} \frac{\left(T_{\text {coll }}-T_{a m b}\right) 2}{G_{\text {tilt }}}
\end{aligned}
$$

where, $\eta_{o}$ denotes the optical efficiency of the collector (-), and $C_{1}$ and $C_{2}$ represent the linear and quadratic heat transfer coefficients $\left(\mathrm{W} / \mathrm{m}^{2} \mathrm{~K}\right)$, respectively. $T_{\text {coll }}$ denotes the average fluid temperature in the collector $(\mathrm{K})$ and $G_{\text {tilt }}$ denotes the solar radiation on a tilted surface $\left(\mathrm{W} / \mathrm{m}^{2}\right)$. The temperature difference $\left(\Delta T_{S}\right)$ between the 2-time steps of the storage tank was calculated using Equations 27 and 28.

$\Delta T_{s}=\frac{P_{\text {coll }}^{h}-P_{h B A H}{ }^{h}-P_{S T i l o s s}^{h}}{\rho_{w} \cdot V_{\text {storage }} \cdot C_{w}}$,

$P_{\text {STiloss }}^{h}=(U . A) s\left(T_{\text {srorage }}-T_{\text {amb }}\right)$,

where, $\rho_{\mathrm{w}}$ denotes the water density $\left(\mathrm{kg} / \mathrm{m}^{3}\right), \mathrm{V}_{\text {storage }}$ denotes the storage tank volume $\left(\mathrm{m}^{3}\right), \mathrm{C}_{\mathrm{w}}$ denotes the specific heat capacity of water $(4.2 \mathrm{~kJ} / \mathrm{kg} . \mathrm{K})$, U denotes the heat loss coefficient $\left(\mathrm{W} / \mathrm{m}^{2} \mathrm{~K}\right)$ of the storage tank, and $\mathrm{A}_{\mathrm{s}}$ denotes the surface area of the storage tank $\left(\mathrm{m}^{2}\right)$. When $\Delta \mathrm{T}_{\mathrm{s}}$ is negative, the heating power of the backup heater is necessary. The backup heater efficiency $\eta_{B A H}$ was calculated to be 0.95 .

$P_{B A H}{ }^{h}=\frac{\left(T_{S T H s e t}-T_{S T H n e w}\right) \cdot V_{\text {storage }} \cdot C_{w} \cdot \rho_{w}}{\eta_{B A H}}$

A positive $\Delta \mathrm{T}_{\mathrm{s}}$ implies the availability of excess heat, which should be stored $\left(\mathrm{P}_{\mathrm{S}}^{\mathrm{h}}\right)$ in the tank as thermal energy.

$P s^{h}=\rho_{w} . V_{\text {storage }} \cdot C_{w} \cdot \Delta T_{S}$

Equation 31 was used to compute the maximum stored daily heat capacity (in $\mathrm{kWh}$ ) of water under the premise that the maximum $\Delta T$ was $20 \mathrm{~K}$.

$Q_{\text {storage }}{ }^{h}=\rho_{w} . V_{\text {storage }} \cdot C_{w} \cdot \Delta T$

The direct heat power $\mathrm{P}_{\text {Direct }} \mathbf{h}$, which drove the chiller to create the direct cooling power (on the premise that the system does not have a storage tank), was computed. 
$\mathrm{P}_{\text {Direct }}^{\mathrm{h}}=\mathrm{P}_{\mathrm{hABCH}}{ }^{\mathrm{h}}-P_{B A H}{ }^{h}$

The $\mathrm{P}_{\text {Direct }}{ }^{\mathrm{h}}, P_{B A H^{h}}, P S^{h}$, and $P_{h A B H}{ }^{h}$ powers were converted from heating powers to cooling powers $\mathrm{P}_{\text {Direct }}{ }^{\mathrm{C}}, P_{B A H^{C}}, P S^{c}$, and $P_{h A B H}{ }^{c}$, respectively, where the $\mathrm{COP}{ }_{\mathrm{ABCH}}$ was 0.71 , as in the subsequent equations.

$$
\begin{aligned}
& P_{\text {Direct }}^{C}=P_{\text {Direct }}^{h} \times C O P_{A B C H}, \\
& P S^{c}=P S^{h} \times C O P_{A B C H} \\
& P_{B A H^{C}}=P_{B A H^{h}} \times \mathrm{COP}_{\mathrm{ABCH}}, \\
& P_{h A B H}{ }^{c}=P_{h A B H}^{h} \times \mathrm{COP}_{\mathrm{ABCH}} .
\end{aligned}
$$

\section{Results and Analysis}

In this study, the phrase "direct energy/power cooling compensation" refers to the cooling energy/power that compensates with the cooling requirements of an air-conditioning system. The concept "storage compensation" refers to the refrigeration energy provided to meet the cooling demands of the storage in the air conditioning system. The cooling energy/power provided by the electric grid is called "cooling energy/power backup" in each scenario to compensate for the remaining cooling demand.

\subsection{Thermal Air-Conditioning vs. PV Air- Conditioning}

Fig s. 9-12 depict the estimated increases in the cooling production for both instances up to the near peak cooling demand in summer. There is, in fact, some surplus cooling output. It can be concluded that the contribution of storage in each case in the compensation of the residual cooling demand is insignificant in summer. However, a high back-up cooling power was required to compensate the residual cooling demand owing to elevated demands at night.

Due to a lack of cooling demand, both situations had high overloaded cooling productions in January and December, which resulted in power wastage. In both the situations, this means that there was no storage contribution during these two months. Furthermore, no additional cooling power was required. For both the situations, the additional cooling was comparably equivalent to the external cooling backup power required in February, March, April, May, August,
September, and October. This means that throughout these months, the storage system's contribution was necessary in each situation.

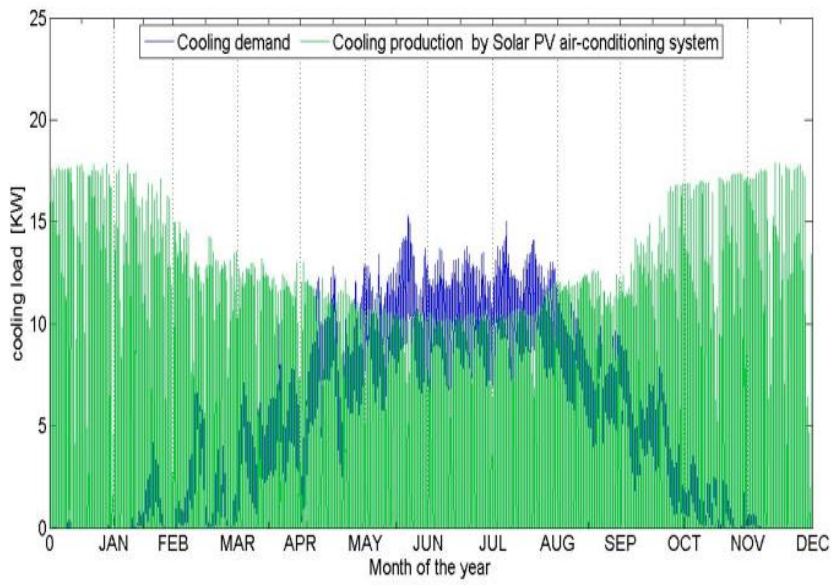

Fig. 9: PV air-conditioning / annual cooling production.

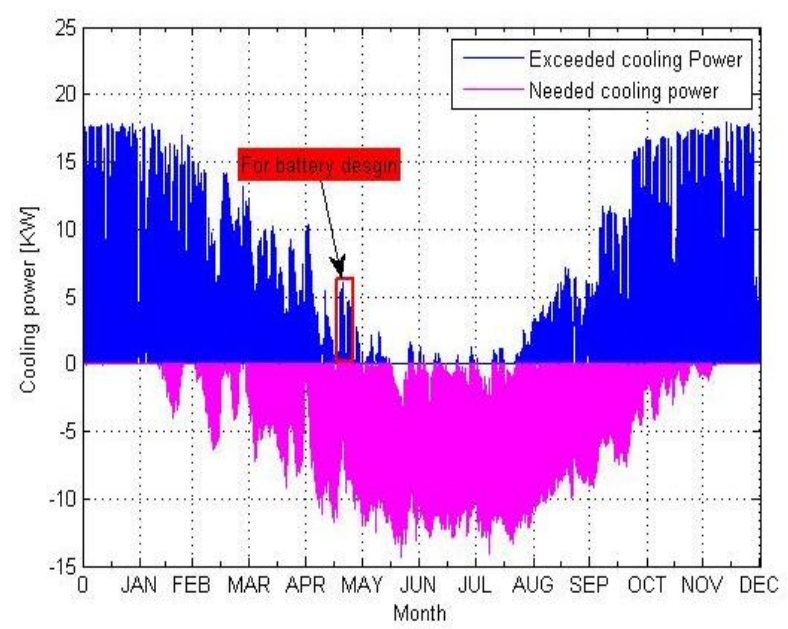

Fig. 10: PV air-conditioning / excess cooling production and back-up cooling.

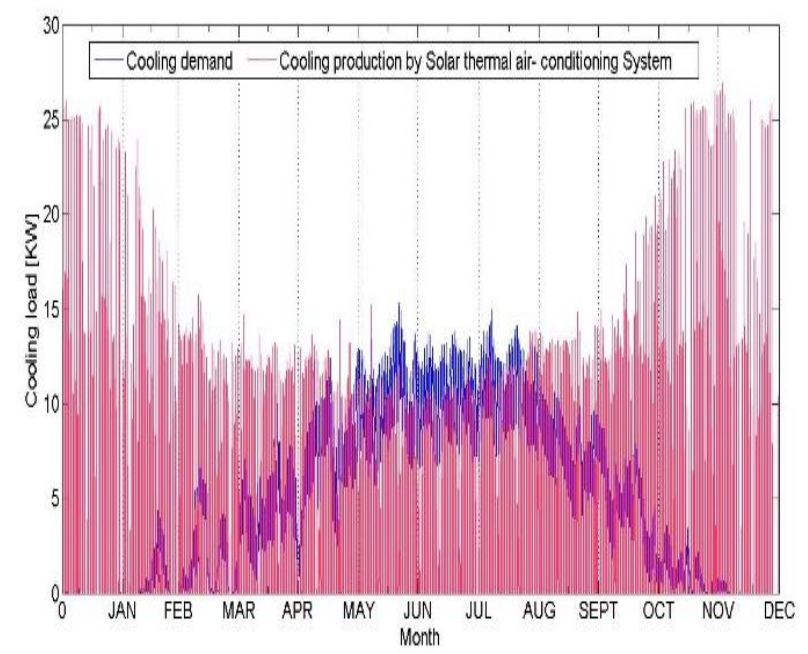

Fig. 11: Production of solar thermal air-conditioning in annual cooling. 


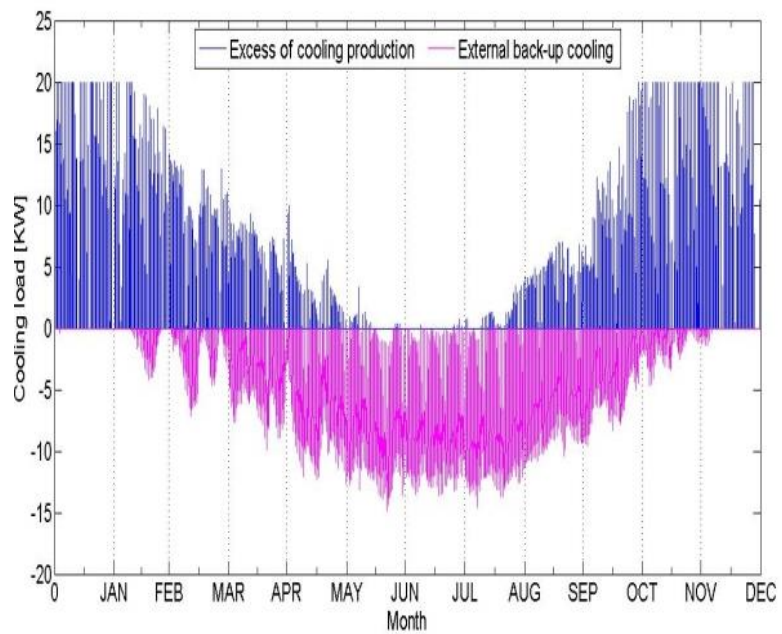

Fig. 12: Solar thermal air-conditioning/excess cooling generation, with external cooling as a backup.

Figs. 13, 14 and 15 show that the daily cooling production of the solar thermal air-conditioning system has a higher peak over the course of a week than that of the solar PV air-conditioning system. A solar thermal air-conditioning system produces more excess cooling than a solar PV air-conditioning system. As a consequence, it can be deduced that the storage system is more necessary and efficient in the thermal air-conditioning system than in the PV airconditioning system.

As shown in Fig. 15, the daily direct cooling compensation given by the PV air-conditioning system in the morning and evening is more than that provided by the thermal air-conditioning system. This can be attributed to the fact that the COPs of the compression and absorption chillers are diametrically opposite ( 3 and 0.7 , respectively), which when compared to the thermal air-conditioning system, enhances the efficiency of the PV air-conditioning system. Furthermore, low ambient air temperatures in the evening and early morning cause thermal losses that exceed the solar gain from the flat plate collector. These losses are in addition to the thermal losses of the storage tank. Moreover, the PV module works during less intense solar radiations early in the morning and evening.
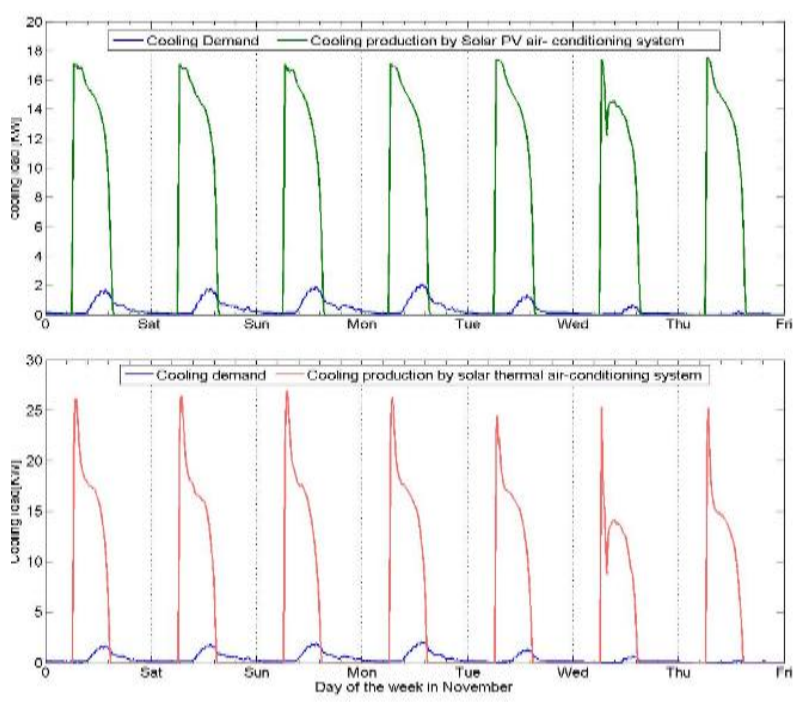

Fig.13 Performance of PV air-conditioning vs. solar thermal air-conditioning during a week in winter.

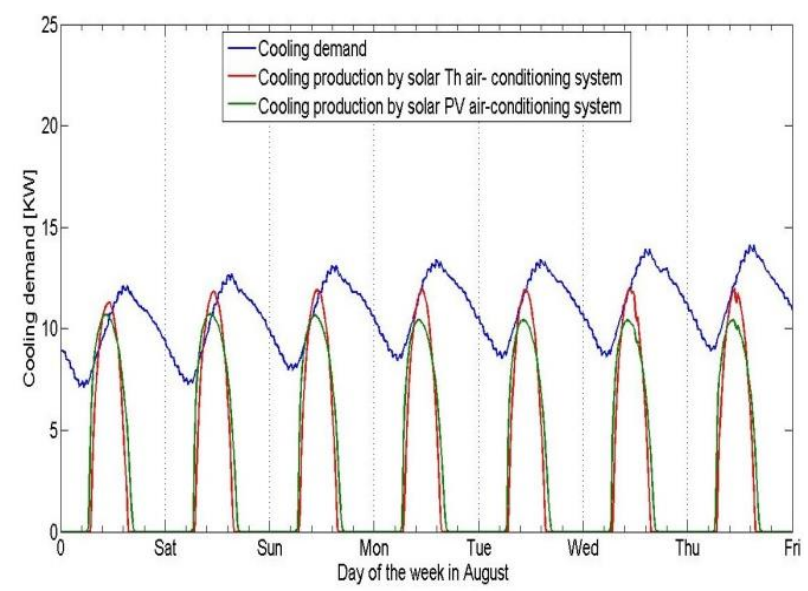

Fig. 14: Performance of PV air-conditioning vs. solar thermal air-conditioning during a week in summer.

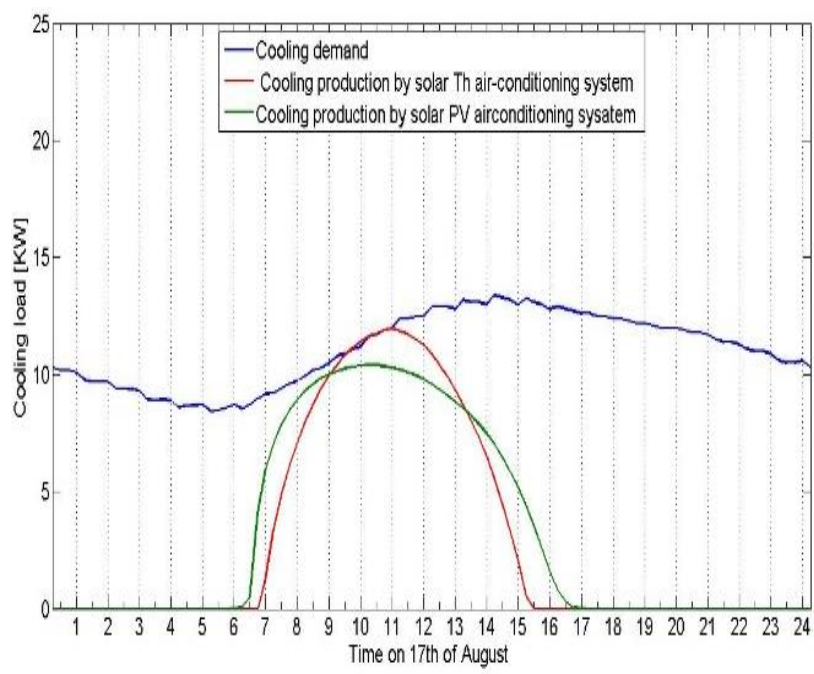

Fig. 15: Performance of PV air-conditioning vs. solar thermal air-conditioning on a summer day.

According to Figs. 16 and 17, the overall annual percentage of cooling energy compensation (direct 
plus storage) provided by the solar thermal airconditioning system was $42.8 \%$, while the PV airconditioning system contributes $43.1 \%$. The difference in the percentages between the two cooling methods was less than $0.3 \%$. However, there were variations in the cooling compensation provided by the storage and the direct cooling system.

The direct cooling compensation for PV air-annual conditioning was $35.8 \%$, which was higher and more efficient than the cooling compensation for the thermal air-direct conditioning (30.9\%). As a result, the COP affects the overall system efficiency. Furthermore, the PV modules provide power in the morning and evening. The thermal air-conditioning system creates no cooling power owing to thermal losses at the flat plate collectors, thereby demonstrating the presence of cooling power. Thus, the thermal losses significantly occur during winter, autumn, and spring seasons, where there is sunshine and low ambient temperature surrounding the solar flat plate during the daytime.

In the thermal air-conditioning system, the storage tank compensated for $11.9 \%$ of the cooling energy, which was higher than the storage compensation in PV air-conditioning (7.3\%). This can be attributed to the additional surplus power of the flat plate collector in comparison with the PV module output power during noon. This assists in compensating for the cooling requirement of the storage during night time.

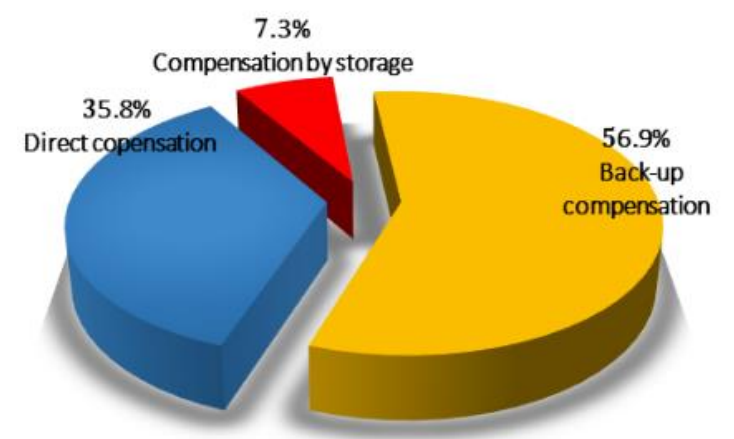

Fig. 16: Solar PV air-conditioning system / annual percentage of cooling energy compensation.

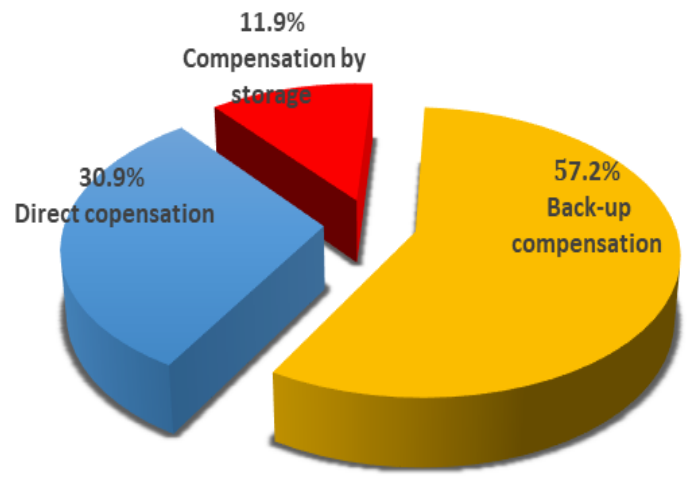

Fig. 17: Solar thermal air-conditioning system/annual percentage of cooling energy compensation.

\section{Conclusions}

The results pertaining to the thermal energy demands contribute to the external solar radiation and ambient temperature profiles. It indicates the necessity of cooling compared to heating for SFHs in Aqaba city. Furthermore, it is necessary to consider night cooling as well as daytime cooling in Aqaba. The annual direct cooling compensation of the PV airconditioning system was $35.8 \%$, which was technically more favourable than that of the thermal air-conditioning system, i.e., $30.9 \%$. This is attributed to the difference between the COPs of the compressed and absorption chillers. Furthermore, based on the daily cooling generation profile, in the morning and evening time the PV modules generate electrical power which indicates the presence of cooling power in these times while there is no cooling power generation by thermal airconditioning system due to thermal losses at flat plate collectors where there is low direct radiation and ambient temperature.

Based on the study's boundary circumstances, these conclusions help in the following decision-making: storage system compensation in the PV airconditioning system is minor, while direct cooling compensation is considerable. However, in the case of a solar thermal air-conditioning system, the opposite is true. More research should be conducted to assess and compare the two technology classes in terms of heat pump systems, storage systems, building location, and economic analyses. 


\section{References:}

[1] P. J. Martínez, P. Martínez, V. M. Soto, L. A. Bujedo, and J. Rodriguez, "Design of A $35 \mathrm{KW}$ Solar Cooling Demonstration Facility for a Hotel in Spain," Appl. Sci., vol. 10, no. 2, 2020, doi: 10.3390/app10020496.

[2] F. M. Montagnino, F. Paredes, A. Giaconia, and N. Fylaktos, "Solar Multi-Generation in the Mediterranean Area, the Experience of the Sts-Med Project," in 11th ISES EuroSun Conference, 2016, pp. 1-9, doi: 10.18086/eurosun.2016.05.06.

[3] F. M. Montagnino, "Solar Cooling Technologies. Design, Application and Performance of Existing Projects," Sol. Energy, vol. 154, no. 2017, pp. 144157, 2017, doi: 10.1016/j.solener.2017.01.033.

[4] D. Neyer, D. Mugnier, A. Thür, R. Fedrizzi, and P. G. V. Quiles, "Solar Heating and Cooling \& Solar Air-Conditioning," IEA Int. Energy Agency, vol. SHC Solar, no. November, 2018.

[5] J. A. Duffie and W. A. Beckman, "Solar Engenierring of Thermal Process." p. 893, 2006.

[6] C. T. Banhardt and C. Nytsch-Geusen, "Simulation Based Design of a Test Rig for Developing Solar Cooling Concepts for the MENA Region," in Building Simulation Cairo 2013 - Towards Sustainable \& Green Built Environment, 2013, pp. $1-10$.

[7] L. Huang, R. Zheng, and U. Piontek, "Installation and Operation of a Solar Cooling and Heating System Incorporated with Air-Source Heat Pumps," Energies, vol. 12, no. 6, 2019, doi: 10.3390/en12060996.

[8] M. Jaradat, M. Al-Addous, A. Albatayneh, Z. Dalala, and N. Barbana, "Potential Study of Solar Thermal Cooling in Sub-Mediterranean Climate," Appl. Sci., vol. 10, no. 7, 2020, doi: 10.3390/app10072418.

[9] A. Shirazi, R. A. Taylor, G. L. Morrison, and S. D. White, "Solar-Powered Absorption Chillers: A Comprehensive and Critical Review," Energy Convers. Manag., vol. 171, no. January, pp. 59-81, 2018, doi: 10.1016/j.enconman.2018.05.091.

[10] V. Quaschning and M. B. Muriel, "Solar Power Photovoltaics or Solar Thermal Power Plants?," 2001.

[11] N. Hartmann, C. Glueck, and F. P. Schmidt, "Solar Cooling for Small Office Buildings: Comparison of Solar Thermal and Photovoltaic Options for Two Different European Climates," Renew. Energy, vol. 36, no. 5, pp. 1329-1338, 2011, doi: 10.1016/j.renene.2010.11.006.

[12] A. Thür, T. Calabrese, and W. Streicher, "Smart Grid and PV Driven Ground Heat Pump as Thermal Battery in Small Buildings for Optimized Electricity Consumption," Sol. Energy, vol. 174, no. July, pp. 273-285, 2018, doi: 10.1016/j.solener.2018.08.087.

[13] H. Schwarz, H. Schermeyer, V. Bertsch, and W. Fichtner, "Self-Consumption Through Power-ToHeat and Storage for Enhanced PV Integration in
Decentralised Energy Systems," Sol. Energy, vol. 163, no. January, pp. 150-161, 2018, doi: 10.1016/j.solener.2018.01.076.

[14] D. Neyer, M. Ostheimer, C. Dipasquale, and R. Köll, "Technical and Economic Assessment of Solar Heating and Cooling - Methodology and Examples of IEA SHC Task 53," Sol. Energy, vol. 172, no. February, pp. 90-101, 2018, doi: 10.1016/j.solener.2018.02.070.

[15] B. W. Sparber, A. Napolitano, G. Eckert, and A. Preisler, "Task 38 Solar Air-Conditioning and Refrigeration 'State of The Art of Existing Solar Heating and Cooling Systems,"” 2009.

[16] B. R. Qawasmeh, A. Al-salaymeh, S. Sari, N. Elian, and N. Zahran, "Energy Rating for Residential Buildings in Amman," he Int. J. Therm. Environ. Eng., vol. 14, no. 2, pp. 109-118, 2017, doi: 10.5383/ijtee.14.02.004.

[17] H. M. Henning and E. Wiemken, "Solar Cooling," ISES Sol. World Congr. 2007, ISES 2007, vol. 1, pp. 60-67, 2007, doi: 10.4324/9781849775120-13.

[18] C. Infante Ferreira and D. S. Kim, "TechnoEconomic Review of Solar Cooling Technologies Based on Location-Specific Data," Int. J. Refrig., vol. 39, pp. 23-37, 2014, doi: 10.1016/j.ijrefrig.2013.09.033.

[19] S. Jaber and S. Ajib, "Optimum, Technical and Energy Efficiency Design of Residential Building in Mediterranean Region," Energy Build., vol. 43, no. $8, \quad$ pp. 1829-1834, 2011, doi: 10.1016/j.enbuild.2011.03.024.

[20] S. A. Klein and W. A. Beckman, "Volume 5 Mathematical Reference," TRNSYS 16, vol. 5, p. 389 to $396,2007$.

[21] T. Awadallah, S. Habe, A. Mahasneh, and H. Adas, "Green Building Guideline of Jordan," -Jordan Int. Energy Conf. 2011 - Amman, no. July, 2011.

[22] ASHRAE Handbook, "Fundamentals (I-P Edition)," Am. Soc. Heating, Refrig. Air Cond. Eng. Atlanta, vol. 32, p. TC 4.7, Energy Calculations, 2005.

[23] EnergyPlus, "Weather Data of Jordan," 2012, 2012. https://energyplus.net/weather.

[24] U. Eicker, Solar Technologies for Buildings. 2005.

[25] B. Nienborg, "Solar-Assisted Heating and Cooling of Buildings: Technology, Markets and Perspectives," 2010.

\section{Creative Commons Attribution License 4.0 (Attribution 4.0 International, CC BY 4.0)}

This article is published under the terms of the Creative Commons Attribution License 4.0 https://creativecommons.org/licenses/by/4.0/deed.en US 